\title{
Some Quality Traits of Different Wild Plants
}

\author{
Mehmet BASBAG ${ }^{1}$, Ramazan DEMIREL $^{2)}$, Mustafa AVCI $^{3)}$ \\ ${ }^{1)}$ Dicle University Faculty of Agriculture, Department of Field Crops, Diyarbakir,Turkey; mbasbag@dicle.edu.tr \\ 2) Dicle University Faculty of Agriculture, Department of Animal Science, Diyarbakir, Turkey; ramazand@dicle.edu.tr \\ 3) Agricultural Research Institute of Cukurova, Department of Field Crops, Adana, Turkey; mavci61@hotmail.com
}

\begin{abstract}
This research was carried out to determine quality properties of some pasture plant species. In this research, 10 different pasture plant species were used as materials which were collected from Diyarbakir pasture areas of Turkey. At the end of research, quality properties of pasture plants were ranged from lowest to highest for average dry matter 11.5-30.9\%, average crude protein 12.6-26.6\%, crude ash 5.5-21.2\%, acid detergent fiber 22.0-43.0\%, neutral detergent fiber 20.5-56.1\%, digestible dry matter 55.4-71.8\%, dry matter intake 2.1-5.9\% and relative feed value 90.2-327.0. Among the pasture plants studied, higher crude protein level than averages of species following plants may have importance, respectively: Centaurea iberica, Sinapsis arvensis, Convolvulus arvensis, Rumex conglomeratus, Crambe orientalis, Amaranthus retroflexus, Polygonum aviculare, Anchusa strigosa and Malva neglecta. For relative feed value has been remarked: Sinapsis arvensis, Rumex conglomeratus, Amaranthus retroflexus, Crambe orientalis, Centaurea iberica and Hypecoum imberbe.
\end{abstract}

Keywords: pasture plants, acid detergent fiber, neutral detergent fiber, relative feed value, digestible dry matter, average crude protein

\section{Introduction}

There were a lot of plants in natural pasture areas. These plants have important role in feeding of animals. In addition to natural forage crops, these plants were prefered sometimes by animals. This kind of plants usually does not prefer in rangelands. However, the number of valuable plants decreases in pasture composition, animals prefer these kinds of plants as seconderily. Nutritional properties of these seconderily preferred plants are inadequate in literatures.

These plants which takes place in pasture composition can be prefered by different animal species. At the same time, these plants covering pasture areas prevent from soil erosion problems. Detailed and updated data about these plant species in the study were supplied from Flora of Turkey (Davis, 1965-1982). There are some literatures about our studied plants for some quality properties. Kamalak et al. (2005) have stated that Sinapsis arvensis in early, mid and late flowering stage; for dry matter, crude protein, ADF, NDF and crude ash values as 95.9-96.5\%, 7.7-13.2\%, 56.4-65.8\%, 66.5-74.1\% and 5.6-8.6\%, respectively. Preston (2008) has stated that in Crambe meal; crude protein, ADF, NDF and crude ash percentages as $31,35,47$ and $8 \%$, respectively. Crude protein contents were changed from $12.12 \%$ (Acar and Guncan, 2002) to 20.65\% (Kaya et al., 2004) in Poligonum aviculare. Stordahl et al. (1999) have pointed out in Amaranth species (A. cruentus L. and $A$. kypochondriacus L.) at 8 weeks after planting, crude protein, ADF and NDF percentages were found (23, 26 and 36\%) respectively. In Amaranthus retroflexus dry matter, crude ash and crude protein percentage reach to $18.2 \%, 22.8 \%, 3.4 \%$ (Sekeroglu et al., 2006). Bakoglu et al. (1999) have pointed that crude protein as $15.35 \%$ and crude fiber $30.48 \%$ in Achillea biebersteini. Alvarez et al. (2008) have pointed that crude protein as 12.9\%, dry matter $21.7 \%$, ADF $24.8 \%$ and NDF $39.8 \%$ in Rumex lunaria. Bakoğlu et al. (1999) have pointed that crude protein as $13.74 \%$ and crude fiber $42.31 \%$ in Rumex patientia. Sleugh et al. (2001) have stated that different Amaranthus ssp. at different growing stages for crude protein, ADF and NDF values were change between (8.0$28.5 \%, 15.0-35.4 \%$ and 26.0-47.0\%), respectively. Crude protein contents have pointed that $13.06 \%$ in Malva neglecta (Acar and Guncan, 2002), 26.25\% in Malva sylvestris (Kaya et al., 2004). Acar and Guncan (2002), pointed out $17.70 \%$ crude protein content in Convolvulus arvensis. Acar and Guncan (2002), stated that $12.26 \%$ crude protein content in Tragopogon latifolium.

\section{Materials and methods}

The research was carried out for determining of some nutrient contents in some pasture plants (Tab. 1).

Plant species were collected from the campus area (altitude $655 \mathrm{~m}$ ) of Dicle University, in Diyarbakır, in 2008, Turkey.

Generally, Mediterranean and East Anatolian continental climates are dominant in this region. The average annual temperature is $15.8^{\circ} \mathrm{C}$, rainfall is $481.6 \mathrm{~mm}$ and the 


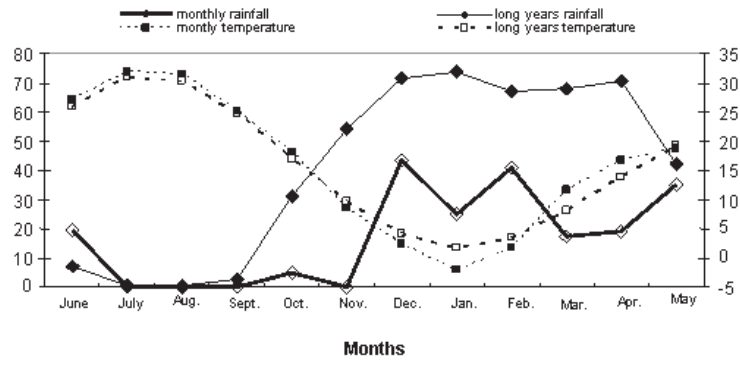

Fig. 1. Average air temperatures $\left({ }^{\circ} \mathrm{C}\right)$ and the amount of rainfall $(\mathrm{mm})$ of the research area

average relative humidity is about $53.8 \%$. The average temperature can reach $30^{\circ} \mathrm{C}$ in July and August. The lowest average temperature can be $7^{\circ} \mathrm{C}$ in December and January. The earliest frost in the region is usually at the end of October and the last frost around end of April. Most rain falls in winter, and there is almost no rainfall from July to September. The highest humidity (70\%) occurs in winter, lowest $(27 \%)$ in summer. Weather conditions during the years when the research was carried out, are given in Fig. 1 (Anonymous, 2008).

Tab. 1. Latin, common and family names and ontogeny of plant species

\begin{tabular}{|c|c|c|c|}
\hline Latin Name & $\begin{array}{c}\text { Common } \\
\text { Name }\end{array}$ & Family & Ontogeny \\
\hline $\begin{array}{l}\text { Hypecoum } \\
\text { imberbe } \mathrm{Sm} \text {. }\end{array}$ & $\begin{array}{l}\text { Sicklefruit } \\
\text { Hypecoum }\end{array}$ & Fumariaceae & Annual \\
\hline $\begin{array}{l}\text { Sinapsis } \\
\text { arvensis } \mathrm{L} \text {. }\end{array}$ & Wild Mustard & Brassicaceae & Annual \\
\hline $\begin{array}{l}\text { Crambe } \\
\text { orientalis } \mathrm{L} \text {. }\end{array}$ & Crambe & Brassicaceae & Perennial \\
\hline $\begin{array}{l}\text { Polygonum } \\
\text { aviculare } \mathrm{L} \text {. }\end{array}$ & $\begin{array}{l}\text { Prostrate } \\
\text { knotweed }\end{array}$ & Polygonaceae & $\begin{array}{c}\text { Annual, } \\
\text { Perennial (P) }\end{array}$ \\
\hline $\begin{array}{l}\text { Amaranthus } \\
\text { retroflexus } \mathrm{L} .\end{array}$ & $\begin{array}{l}\text { Redroot } \\
\text { amaranth }\end{array}$ & Amaranthaceae & Annual \\
\hline $\begin{array}{l}\text { Achillea } \\
\text { biebersteinii } \\
\text { Afan. }\end{array}$ & Yarrow & Asteraceae & Perennial \\
\hline $\begin{array}{l}\text { Convolvulus } \\
\text { arvensis } L .\end{array}$ & Field bindweed & Convolvulaceae & Perennial \\
\hline $\begin{array}{l}\text { Malva neglecta } \\
\text { Wallr. }\end{array}$ & $\begin{array}{l}\text { Common } \\
\text { mallow }\end{array}$ & Malvaceae & $\begin{array}{l}\text { Annual, } \\
\text { Biennial, P }\end{array}$ \\
\hline $\begin{array}{l}\text { Anchusa } \\
\text { strigosa Labill. }\end{array}$ & Bugloss & Borraginaceae & Perennial \\
\hline $\begin{array}{l}\text { Centaurea } \\
\text { iberica Trev. } \\
\text { ex Spreng. }\end{array}$ & $\begin{array}{c}\text { Iberian } \\
\text { knapweed }\end{array}$ & Asteraceae & Perennial \\
\hline $\begin{array}{l}\text { Rumex } \\
\text { conglomeratus } \\
\text { Murray }\end{array}$ & Clustered dock & Polygonaceae & Perennial \\
\hline $\begin{array}{l}\text { Tragopogon } \\
\text { dubius Scop. }\end{array}$ & Yellow salsify & Asteraceae & $\begin{array}{l}\text { Annual, } \\
\text { Biennial }\end{array}$ \\
\hline
\end{tabular}

All of the plants were collected at mid flovering stage. Common names of the plants were used according to Anonymous (2009a).

Plant samples were dried at $70^{\circ} \mathrm{C}$ in a drying cabin (Memmert ULM 800) for 12 hours. Acid detergent fiber (ADF), neutral detergent fiber (NDF) were determined by Ankom Fiber Analizer (Model 220), crude protein (CP) were determined by Kjeldahl method, after samples were ground. Crude ash values were determinated at $550^{\circ} \mathrm{C}$ for 6 hours in oven.

Digestible dry matter (DDM), dry matter intake (DMI) and relative feed value (RFV) were calculated by using following equations (Morrison, 2003):

$$
\begin{aligned}
& \mathrm{DDM}=88.9-(0.779 \times \mathrm{ADF}) \\
& \mathrm{DMI}=120 \div \mathrm{NDF} \\
& \mathrm{RFV}=(\mathrm{DDM} \times \mathrm{DMI}) \div 1.29
\end{aligned}
$$

\section{Results and discussion}

Average dry matter (DM), crude protein (CP), crude ash (CA), acid detergent fiber (ADF), neutral detergent fiber (NDF), digestible dry matter (DDM), dry matter intake (DMI) and relative feed value (RFV) contents of all investigated plants were obtained as follows; 18.9, 21.6, $14.0,29.5,32.0,65.9,4.1$ and $215.3 \%$, respectively (Tab. 2).

The highest DM, CP, CA, ADF, NDF, DDM, DMI and RFV values were obtained from Achillea biebersteinii (30.9\%), Centaurea iberica (26.6\%), Amaranthus retroflexus (21.2\%), Anchusa strigosa (43\%), Anchusa strigosa (56.1\%), Rumex conglomeratus (71.8\%), Sinapsis arvensis (5.9\%) and Sinapsis arvensis (327.0\%), respectively. However, the lowest values were obtained from Anchusa strigosa (11.5\%), Achillea biebersteinii (12.6\%), Convolvulus arvensis (5.5\%), Rumex conglomeratus (22.0\%), Sinapsis arvensis (20.5\%), Anchusa strigosa (55.4\%), Anchusa strigosa (2.1\%) and Anchusa strigosa (90.2\%), respectively.

Achillea biebersteinii: The lowest CP (12.6\%), lower $\operatorname{DDM}(58.2 \%)$ and RFV (121.8) values were obtained in this plant. When we consider this quality properties it seems that this plant has not enough nutritional value as roughage. In previous research, crude protein $15.35 \%$ and crude fiber $30.48 \%$ were obtained in this plant (Bakoğlu et al., 1999). However, it can be grazed in early stage for ruminant animals. In addition, Achillea species have been using in traditional Turkish medicine (Konyalioglu and Karamenderes, 2005).

Amaranthus retroflexus: Higher CP (23.3\%), DDM (70.4\%), DMI (5.3\%), RFV (289.2); the lower ADF (23.8\%) and NDF (22.7\%) values were obtained in this plant. This plant can be prefered as roughage because of it's higher nutritional value. Our findings are similar with the results of Sleugh et al. (2001).

Anchusa strigosa: The lowest RFV (90.2); lower DDM (55.4\%), DMI (2.1\%), however the highest ADF (43.0\%) and NDF (56.1\%) values were obtained in this plant. But, 
Tab. 2. Average Crude Protein (CP), Crude Ash (CA), Acid Detergent Fiber (ADF), Neutral Detergent Fiber (NDF), Digestible Dry Matter (DDM), Dry Matter Intake (DMI) (\%) percentages and Relative Feed Value (RFV) of different plant species

\begin{tabular}{lllllllcc}
\hline \multicolumn{1}{c}{ Plant Species } & $\begin{array}{c}\text { DM } \\
(\%)\end{array}$ & $\begin{array}{c}\text { CP } \\
(\%)\end{array}$ & $\begin{array}{c}\text { CA } \\
(\%)\end{array}$ & $\begin{array}{c}\text { ADF } \\
(\%)\end{array}$ & $\begin{array}{c}\text { NDF } \\
(\%)\end{array}$ & $\begin{array}{c}\text { DDM } \\
(\%)\end{array}$ & $\begin{array}{c}\text { DMI } \\
(\%)\end{array}$ & RFV \\
\hline Achillea biebersteinii & 30.9 & 12.6 & 9.0 & 39.4 & 45.2 & 58.2 & 2.7 & 121.8 \\
Amaranthus retroflexus & 19.5 & 23.3 & 21.2 & 23.8 & 22.7 & 70.4 & 5.3 & 289.2 \\
Anchusa strigosa & 11.5 & 21.4 & 18.4 & 43.0 & 56.1 & 55.4 & 2.1 & 90.2 \\
Centaurea iberica & 15.0 & 26.6 & 17.4 & 27.1 & 23.5 & 67.8 & 5.1 & 268.1 \\
Convolvulus arvensis & 19.9 & 25.2 & 5.5 & 34.4 & 39.2 & 62.1 & 3.1 & 149.2 \\
Crambe orientalis & 20.3 & 24.7 & 14.9 & 24.5 & 23.8 & 69.8 & 5.0 & 270.5 \\
Hypecoum imberbe & 12.7 & 14.8 & 10.6 & 25.6 & 29.3 & 69.0 & 4.1 & 219.3 \\
Malva neglecta & 23.2 & 20.7 & 14.0 & 30.0 & 39.9 & 65.5 & 3.0 & 152.3 \\
Polygonum aviculare & 22.7 & 22.6 & 13.9 & 34.6 & 28.6 & 62.0 & 4.2 & 201.9 \\
Rumex conglomeratus & 16.7 & 24.8 & 12.9 & 22.0 & 22.4 & 71.8 & 5.4 & 300.6 \\
Sinapsis arvensis & 15.2 & 25.7 & 16.9 & 22.3 & 20.5 & 71.5 & 5.9 & 327.0 \\
Tragopogon dubius & 19.0 & 16.5 & 13.2 & 27.5 & 32.2 & 67.5 & 3.7 & 193.6 \\
Average & 18.9 & 21.6 & 14.0 & 29.5 & 32.0 & 65.9 & 4.1 & 215.3 \\
\hline
\end{tabular}

protein content $(21.4 \%)$ of the plant is high. It can be say that this plant has not enough nutritional values, except crude protein. In addition, this plant's roots (Palevitch et al., 1986) and leaves (Dafni et al., 1984) were used in medicine; the plant contains no tannin (Aynehchi et al., 1985).

Centaurea iberica: The highest CP content (26.6\%); higher DDM (67.8\%), DMI (5.1\%), RFV (268.1); lower $\operatorname{ADF}(27.1 \%)$ and NDF (23.5\%) were obtained in Centaurea iberica. Despite, quite high nutrition values, this plant has been classified as a "noxious weed" of cultivated land (Anonymous, 2009c). At the same time, this plant can be grazed by animals in early stages because of it's thistle.

Convolvulus arvensis: Higher protein content (25.2\%); moderate level of ADF (34.4\%), NDF (39.2\%); lower level of DDM (62.1\%), DMI (3.1\%) and RFV (149.2) were found in Convolvulus arvensis. The protein content is higher than other results (Acar and Guncan, 2002).

Crambe orientalis: Higher CP content (24.7\%), DDM (69.8\%), DMI (5.0\%), RFV (270.5) parameters; but lower ADF (24.5\%) and NDF content (23.8\%) were determined in Crambe orientalis. It seems that this plant has important role in animal nutrition as forage. Additionally, Stock et al. (1993) pointed out crambe meal has been used as a protein source for feedlot cattle.

Hypecoum imberbe: Lower level of CP (14.8\%); moderate level of ADF (25.6\%), NDF (29.3\%); higher DDM (69.0\%), DMI (4.1\%) and RFV (219.3) were found in Hypecoum imberbe. Because of it's succulent structure animals can prefer it.

Malva neglecta: Higher protein content (20.7\%); moderate level of ADF (30.0\%), NDF (39.9\%); lower level of DMI (3.0\%) and RFV (152.3) were found in Malva neglecta. The protein content is higher than the results of Acar and Guncan (2002). When we consider the nutrient contents of this plant, it can be used as secondary forage crop. It has been used as forage for camel and in medicinal purposes. (Heshmati and Behmanesh, 2006).

Polygonum aviculare: Higher level of CP (22.6\%); moderate level of ADF (34.6\%), NDF (28.6\%), DDM (62.0\%), DMI (4.2\%) and RFV (201.9) were found in Polygonum aviculare. Our results of CP are similar with the findings of Kaya et al. (2004). Nutrient composition of plant seems adequate for animals. However, this plant is classified as a "noxious weed" of cultivated land (Anonymous, 2009c).

Rumex conglomeratus: The highest DDM (71.8\%); higher crude protein content (24.8\%), DMI (5.4\%), RFV (300.6); lower NDF (22.4\%) and the lowest ADF (22\%) contents were found in Rumex conglomeratus. Our findings for crude protein is higher than the results of some authors (Bakoğlu et al., 1999; Sleugh et al., 2001; Alvarez et al., 2008), but for ADF and NDF are lower than Alvarez et al. (2008). These differences probably are the result of plant species and harvesting stage. When we consider higher CP content and RFV, this plant may has importance in ruminant nutrition.

Sinapsis arvensis: The highest DMI (5.9\%), RFV (327.0) parameters; higher CP (25.7\%), DDM (71.5\%); lower ADF (22.3\%) and the lowest NDF (20.5\%) content were determined in Sinapsis arvensis. In addition, this plant is a serious weed of cultivated land (Anonymous, $2009 b$ ). Besides, it can be use in animal nutrition as forage by grazing or collected for winter use in Turkey (Kamalak et al., 2005). Our findings about crude protein and crude ash contents are higher, but ADF and NDF values in $\mathrm{Si}$ napsis arvensis are lower than the finding of Kamalak et al. (2005).

Tragopogon dubius: Moderate level of protein content (16.5\%), ADF (27.5\%), NDF (32.2\%), RFV (193.6), DDM (67.5\%) and DMI (3.7\%) were found in Tragopgon 
dubius. Our results of protein content is higher than the results of Acar and Guncan (2002).

As a result, if we consider higher crude protein level than averages of species following plants may have importance: Centaurea iberica, Sinapsis arvensis, Convolvulus arvensis, Rumex conglomeratus, Crambe orientalis, Amaranthus retroflexus, Polygonum aviculare, Anchusa strigosa and Malva neglecta; for RFV Sinapsis arvensis, Rumex conglomeratus, Amaranthus retroflexus, Crambe orientalis, Centaurea iberica, Hypecoum imberbe.

These species have importance as secondarily alternative forage crops in rangelands, especially in degenerated rangelands.

\section{Acknowledgments}

The authors thank Professor Dr. Selcuk Ertekin, Department of Biology, Dicle University for identification of the plants.

\section{References}

Acar, R. and A. Guncan (2002). Determination of the Morphological Characteristics and Crude Protein Contents of some Wild Species which Can be Used as Forage Crops. Selcuk University Journal of Agricultural Sciences. 16(29):79-83.

Alvarez, S., P. Mendez, C. Diaz, H. Briggs and M. Fresno (2008). Forage from the Canary Isles (Spain) Adapted to Arid Lands. Journal of Animal and Veterinary Advances. 7(3):359-363.

Anonymous (2008). Meteorological Data of DiyarbakirTurkey.

Anonymous (2009a). United States Department of Agriculture. Naturel Resources Conservation Service (USDA). Plants Database. http://plants.usda.gov.

Anonymous (2009b). Ministry of Agriculture Food \& Rural Affairs. http://www.omafra.gov.on.ca/english/crops/ facts/03-043.htm.

Anonymous (2009c). California Department of Food and Agriculture http://www.cdfa.ca.gov/phpps/ppd/index. html.

Aynehchi, Y., M. H. Salehi-Sormaghi, G. H. Amin, M. Khoshkhow and A. Shabani (1985). Survey of Iranian Plants for Saponins, Alkaloids, Flavonoids and Tannins III. International Journal of Crude Drug Research. 23:33-41.

Bakoglu, A., A. Koc and A. Gokkus (1999). Some Characteristics of the Common Plants of Range and Meadows in Erzurum in Relation to Life Span, Beginning of the Flowering and Forage Quality. Turkish Journal of Agriculture and Forestry.
23(4):951-957.

Dafni, A., Z. Yaniv and D. Palevitch (1984). Ethnobotanical Survey of Medicinal Plants in Northern Israel. Journal of Ethnopharmacology. 10:295-310.

Davis, P. H. (1965-1982). Flora of Turkey and East Eagen Islands. Edinburgh at the University Press. 1:272-273.

Kamalak, A., O. Canbolat, Y. Gurbuz, C. O. Ozkan and M. Kizilsimsek (2005). Determination of Nutritive Value of Wild Mustard (Sinapsis arvensis) Harvested at Different Maturity Stages Using in Situ and in Vitro Measurements. Asian-Australasian Journal of Animal Sciences. 18(9):12491254.

Kaya, I., N. Incekara and Y. Nemli (2004). Ingredients of Some Weeds Consumed As Food in Aegean Region. Yuzuncu Yil University Journal of Agricultural Sciences. 14(1):1-6.

Konyalioglu, S. and C. Karamenderes (2005). The Protective Effects of Achillea L. Species Native in Turkey Against $\mathrm{H}_{2} \mathrm{O}_{2}$-Induced Oxidative Damage in Human Erythrocytes and Leucocytes. Journal of Ethnopharmacology. 102:221227.

Morrison, J. A. (2003). Hay and Pasture Management, Chapter 8. Extension Educator, Crop Systems Rockford Extension Center. http://iah.aces.uiuc.edu/pdf/Agronomy_HB/ 08chapter.pdf.

Palevitch, D., Z. Yaniv, A. Dafni and J. Friedman (1986), pp.281345. Medicinal Plants of Israel. In: L. Craker \& J. Simons (eds). Herbs, Spices and Medicinal Plants. I.

Preston, R. L. (2008). Typical Composition of Feeds for Cattle and Sheep. http://www.beefmagazine.com.

Sekeroglu, N., F. Ozkutlu, M. Deveci, O. Dede and N. Yilmaz (2006). Evaluation of some Wild Plants Aspect of Their Nutritional Values Used as Vegetable in Eastern Black Sea Region of Turkey. Asian Journal of Plant Sciences. 5(2):185189.

Sleugh, B. B., K. J. Moore, E. C. Brummer, A. D. Knapp, J. Russell and L. Gibson (2001). Forage Nutritive Value of Various Amaranth Species at Different Harvest Dates. Crop Science 41:466-472.

Stock, R., R. Britton, T. Klopfenstein, K. Karges, C. Krehbiel and R. Huffman (1993). Feeding Value of Crambe Meal. Nebraska Beef Cattle Report. pp.51-53. Lincoln.

Stordahl, J. L., C. C. Sheaffer, A. DiCostanzo (1999). Variety and Maturity Affect Amaranth Forage Yield and Quality. Journal of Production Agriculture. 12:249-253. 